\title{
Article
}

\section{Measures of sensation in neurological conditions: A systematic review}

Connell, Louise and Tyson, S.F

Available at http://clok.uclan.ac.uk/6794/

Connell, Louise ORCID: 0000-0002-0629-2919 and Tyson, S.F (2012) Measures of sensation in neurological conditions: A systematic review. Clinical Rehabilitation, 26 (1). pp. 68-80. ISSN 0269-2155

It is advisable to refer to the publisher's version if you intend to cite from the work. http://dx.doi.org/10.1177/0269215511412982

For more information about UCLan's research in this area go to http://www.uclan.ac.uk/researchgroups/ and search for < name of research Group>.

For information about Research generally at UCLan please go to http://www.uclan.ac.uk/research/

All outputs in CLoK are protected by Intellectual Property Rights law, including Copyright law. Copyright, IPR and Moral Rights for the works on this site are retained by the individual authors and/or other copyright owners. Terms and conditions for use of this material are defined in the policies page.

\section{CLoK}

Central Lancashire online Knowledge www.clok.uclan.ac.uk

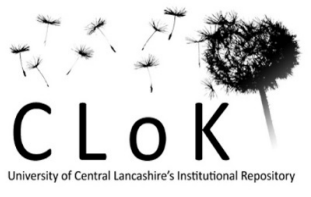




\section{Measures of sensation in neurological conditions: a systematic review}

Objective: To systematically review the psychometric properties and clinical utility of measures of sensation in neurological conditions to inform future research studies and clinical practice.

Data sources: Electronic databases (MEDLINE, CINAHL, EMBASE and AMED) were searched from their inception to December 2010.

Review methods: Search terms were used to identify articles that investigated any sensory measures in neurological conditions. Data about their psychometric properties and clinical utility were extracted and analysed independently. The strength of the psychometric properties and clinical utility were assessed following recommendations (1).

Results: 16 sensory measures were identified. Inter-rater reliability and redundancy of testing protocols are particular issues for this area of assessment. 11 were rejected because they were not available for a researcher or clinician to use. Of the remaining 5 measures, the Erasmus MC modifications of the Nottingham Sensory Assessment and the Sensory section of the Fugl-Meyer Assessment showed the best balance of clinical utility and psychometric properties.

Conclusion: Many measures of sensory impairment have been used in research but few have been fully developed to produce robust data and be easy to use. At present, the sensory section of the Fugl-Meyer Assessment and the Erasmus MC modifications of the Nottingham Sensory Assessment show the most effective balance of usability and robustness, when delivered according to the operating instructions. 


\section{Introduction}

There is a clinical and research driver for the use of objective measurement tools in rehabilitation. Clinically, the use of objective measures is explicitly stated as a core standard in professional and clinical guidelines (2-4). In research, the need for consistent use of measurement tools to aid comparison and meta-analysis has been recognised (5-7). However 'gold standard' measures are lacking and little advice exists around which measurement tools should be measured for different domains and patient populations (8-10). This paper is part of a series which systematically reviewed the psychometric properties and clinical utility (the feasibility of using measurement tools) to identify those which would be most suitable for use in practice and research. It considers measures of sensory impairment.

Sensory impairment, defined as impairments in somatic sensations (body senses such as touch, temperature, pain and proprioception)(11) is common in neurological conditions. It is thought to be related to physical functioning (12-14). A recent qualitative study established that sensory impairment is often of concern to patients, highlighting the need for accurate assessment so that effective, patient-centred interventions can be implemented. Health care professionals have identified that sensory assessment is an essential part of the clinical assessment process and provides useful information for prognosis of functional ability and length of stay (15), however the methods of achieving this are inconsistent and no gold standard is established (13). Our aim therefore was to systematically review the psychometric properties and clinical utility of measures of sensation in all neurological conditions (excluding non-cerebral lesions) to inform future research studies and clinical practice. 


\section{Method}

The method developed for this project has been reported in detail in the reviews of previous domains $(16,17)$ and is reproduced here with the aspects that are specific to the review of measures of sensation.

\section{Study identification and selection}

Electronic databases (MEDLINE, CINAHL, EMBASE and AMED) were searched from their inception to December 2010 using the following keywords:

'outcome' or 'measure' or 'measurement' or 'assessment' or 'test' or 'scale' or 'index' or 'tool' or 'evaluation'

and

‘sens\$' or 'somato-sensory' or ‘afferent' or 'tactile' or 'touch' or 'proprioception' or 'proprioceptive' or 'joint position' or 'joint movement'

and

'stroke' or 'cerebro-vascular accident' or 'hemiplegia' or 'hemi\$' or 'parkinson\$' or 'multiple sclerosis' or 'head injury' or 'brain injury' or 'guillan-barre' or 'motor neurone disease' or 'amyotrophic lateral sclerosis'.

The reference lists of papers were also screened and individual searches made of named tests (Nottingham Sensory Assessment, Rivermead Assessment of Somatosensory Perception, Semmes-Weinstein filaments, Distal Proprioception test; joint position sense evaluation; Friction Discrimination Test ; Weight Matching Test; Hand Active Sensation Test and individual authors: N Lincoln, C Winward, JL Crow, 
S Hillier, L Carey. These were tests and authors that were recurrent in the initial search and intended to ensure the search was as extensive as possible.

All searches were limited to English language and human adults. We excluded articles that involved people with non-cerebral lesions (such as spinal cord injuries or peripheral nerve lesions) and the following from the analysis:

- Articles which measured psychometric properties other than those listed in the method section below

- Composite measures which included sensation as part of a wider assessment of general motor function from which data on sensation could not be extracted.

- Instrumented measures or devices which had no information about how the device could be obtained, or insufficient information about the operating instructions to be obtained or developed, or was clearly not commercially available

- Instrumented measures which clearly could not be used at the bedside such as sensory evoked potential, functional Magnetic Resonance Imaging.

Data about the psychometric properties and clinical utility of the measures were extracted from the selected articles by volunteer neurological physiotherapists from National Health Service Trusts across the North-West of England using standardised instructions and data extraction forms and with support from the authors (see 17 for further details).

\section{Data extraction}


The extracted data was checked and then independently analysed by LC and ST to assess the clinical utility and psychometric properties. Disagreements were discussed amongst the authors and a consensus was reached. Clinical utility refers to the practical details of using a measurement tool and was scored as follows:

- $\quad$ Time taken to administer, analyse and interpret the measurement tool: $3=<10$ minutes $2=10-30$ minutes $1=30-60$ minutes $0=>1$ hours

- $\underline{\text { Cost }}$

$$
3=<£ 100 \quad 2=£ 100-£ 500 \quad 1=£ 500-£ 1,000 \quad 0=>£ 1000 \text { or Unknown }
$$

- Does the measurement tool need specialist equipment and training to use?

$2=$ No: $\quad 1=$ Yes, but simple \& clinically feasible:

$0=$ yes and not feasible for use clinical use / Unknown

- Is the measurement tool portable? Can it be taken to the patient?

2 = yes easily (can fit in a pocket): 1 = Yes (in a briefcase or trolley)

$0=$ No or very difficult

These scores were summated with a maximum score of 10 . Tools scoring less than 8 were considered infeasible for use in clinical practice and were rejected at this stage. Those scoring 8 and above were considered feasible and their psychometric properties were assessed to identify those which would provide robust data. The psychometric properties assessed were reliability (inter-rater and test-retest), concurrent or criterion-related validity and ability to detect change. The accepted methods to assess these properties were:

- For reliability: intra-class correlations (for parametric data) or kappa statistics (for non-parametric data) 
- For validity: Correlation co-efficients

- For ability to detect change: measurement error, standardised response mean, standardised error of measurement; limits of agreement; minimal detectable change.

The strength of the psychometric properties were assessed as recommended (1):

$+\quad$ weak reliability or validity $=$ scores of $0.4-0.6$;

$++\quad$ moderate reliability or validity $=$ scores of $0.6-0.8$

+++ good reliability or validity $=$ scores of 0.8 and above

As data from the tests of ability to detect change are non-standardised, the acceptable (or unacceptable) limits were not specified but considered individually. Bland and Altman plots were also accepted as measures of reliability.

A measurement tool needed to obtain 'good' scores for reliability and validity and have some information about the ability to detect change before it could be recommended. For ordinal scales, the scaling properties were also considered through an assessment of the hierarchy (co-efficients of scalability or reproducibility), Rasch analysis, factor analysis or internal consistency. If a test had been used to assess the presence or absence of a sensory impairment, the test was included if sensitivity or specificity or the receiver operating characteristic curve had been assessed. In the absence of a recognised gold standard and widely accepted interpretation of these statistics, each test was considered individually. Studies that merely assessed whether a test could detect a difference between groups of healthy individuals or patients or the affected and unaffected hand were excluded. 


\section{Results}

On completion of the searches and screening against the criteria, 16 possible measurement tools were identified. However two of these were rejected as they required sophisticated equipment which were clearly not feasible to use in clinical practice:

- Isokinetic dyanometer (18)

- Electrogoniometers: (19)

Four tests were rejected as they were at prototype stage only:

- Robotic technology (20)

- Custom-built rig (21)

- Magnetic motion tracking system and a sensor. (22)

- Vibrometer (23-25)

A further five tests used much simpler instrumented tests which could be feasibly used in clinical practice (although some had limited portability) and showed good psychometric properties but were not commercially available, could not be reproduced or obtained from the details in the papers. They were also therefore rejected as they could not be used in clinical practice or research. They were the:

- $\quad$ Temporal tactile meter $(26,27)$

- Wrist position sense test (28)

- Tactile Discrimination Test (29)

- Hand Active sensation test: (30)

- $\quad$ AsTex (31) 
This left five remaining assessments which were included in the assessment of clinical utility (Table 1) and are described below. Further details of the studies are shown in Table 2 and their psychometric properties are summarised in Table 3 . The measures that had sufficient clinical utility were the Nottingham sensory Assessment ((revised versions and stereognosis section), the sensory section of Fugl-Meyer Assessment and the Moving \& Sustained Touch-Pressure tests. The Rivermead Assessment of Somato-sensory Perception and the Touch Perception Threshold test both scored below the threshold of $8 / 10$. Most measures had some reliability testing with variable results, though interestingly not all had validity confirmed (other than face validity) and only the Touch Perception Threshold test had the ability to detect change reported.

The Nottingham Sensory Assessment (NSA) is an ordinal scale developed by Lincoln et al (32) that assesses sensory impairments in the face, trunk, upper and lower limbs. The modalities assessed were tactile sensations (light touch, pinprick, pressure, tactile localisation, bilateral simultaneous touch), temperature, proprioception and stereognosis. The complete assessment took about 1 hour to administer and inter-rater reliability was poor (Table 1 and 3). Revisions reduced the items by removing testing of the unaffected side and established a hierarchy with improved reliability (33). Stolk-Hornsveld et al made further revisions (34) (the Erasmus MC modifications of the Nottingham sensory Assessment) by removing the items testing temperature and adding sharp- blunt discrimination. Scoring was standardised more explicitly and a uniform scoring system added (35). This version showed improved inter-rater reliability (Table 3) but two-point discrimination remained unreliable, so was removed. It took only 10-15 minutes to complete (Table 
1), although the scope for further reductions by establishing a testing hierarchy so that not all items needed to be tested was noted.

More recently, Connell (36) explored the concurrent and construct validity of the original Nottingham sensory Assessment using Pearson correlation co-efficients and Rasch analysis. Scores were weak-moderately but significantly related to stroke severity, motor ability and independence in the activities of daily living (Table 2). Low inter-item correlations between modalities and high inter-item correlations between body parts in close proximity to each other were found, particularly in the hand and wrist, and the foot and ankle suggesting redundancy and that only one of each body area needed to be assessed. The assessment did not fit the Rasch model indicating inadequate construct validity (37). This was improved so that a fit was achieved by rescoring some items (mainly bilateral simultaneous touch and proprioception) and removing others.

The stereognosis section of the Nottingham sensory Assessment was also revised (38) when the inter-rater reliability and construct validity were evaluated. Patients attempt to identify ten familiar everyday objects ( $\mathrm{a} 10 \mathrm{p}$ coin, $2 \mathrm{p}$ coin, biro, comb, sponge, pencil, scissors, flannel, cup and glass) while blindfolded by touch with assistance to grasp or manipulate if needed. Inter-rater reliability was fair to excellent; mostly good. Connell (36) found a poor fit with the Rasch model until some items were removed (the ten and two pence coins, biro, scissors and cup) and the scoring altered on others (comb, scissors and glass). This left six items that measured consistently over time and by assessor; the fifty pence piece; pencil; comb; sponge; flannel and glass. 


\section{The Rivermead Assessment of Somato-sensory Perception (RASP) was}

designed as a quick, user-friendly standardisation of the clinical assessment of sensory impairment for use with people with all types of central nervous system disorders (39). Seven tests cover the traditional range of modalities used in clinical assessment and 10 major body parts (the head, hands and foot on both sides). As such they have established face validity in that they had been in clinical use for many years. The tests were sharp/dull discrimination; tactile (detecting and localizing touch), temperature discrimination, proprioception (detecting movement and discriminating direction), extinction and two point discrimination. The whole test takes 20-30 minutes to complete but the tests can be used individually and each take a few minutes. Reliability and concurrent validity has been reported (40) using a Bland and Altman plot to evaluate inter-tester reliability (8-11\% variability with no consistent bias). Unfortunately Pearson correlations assessed test-retest reliability which did not meet the criteria of this review. Concurrent validity was assessed by comparison with weakness, motor function and independence in activities of daily living; weak and non-significant relationships were found for tactile modalities while the relationships with proprioception were weak but significant. However further work by Tyson et al (12) (Table 2) reported moderate and significant correlations between the Rivermead Assessment of Somato-sensory Perception and independence in activities of daily and mobility in patients with acute stroke. Tyson \& Busse (41) demonstrated that sensory impairment can be simply classified as 'intact', 'impaired' or 'absent'. They also showed redundancy in the testing schedule for the tactile and proprioceptive modalities, such that testing could be limited to the palm of the hand, 
dorsum of the foot, the thumb and ankle The ability to detect change has not been tested, nor is it clear whether there is redundancy in the other testing modalities.

\section{Sensory section of the Fugl-Meyer Assessment (FMA-S)}

The sensory section of the Fugl-Meyer Assessment is part of the widely used assessment of motor control (42). It contains 12 three-point items; four for light touch and eight for joint position sense give a maximum score of 24 . For light touch the patient is asked whether they can feel touch on the arms, palms of the hands, legs and soles of the feet on both sides. Joint position sense of the inter-phalangeal joint of the thumb, wrist, elbow and shoulder, big toe, ankle, knee and hip are also tested. Inter-rater reliability was weak to excellent for individual items with proprioception scoring more highly than tests of light touch (43). Cronbach's alpha of $0.94-0.98$ indicates that the items measured a single construct (43). Concurrent validity with respect to independence in the activities of daily living (Barthel Index) and motor control (motor section of the Fugl-Meyer Assessment) was weak to moderate but significant (43).

Moving \& Sustained Touch-Pressure Tests(44): The moving touch-pressure test assesses the intensity of sensation felt using (paint) brushes of different stiffnesses. Patients indicate which brush contacted the fingertip on both sides. The brushes to be used and the manner of application are specified. The scores are presented as the percentage of correct responses. The second test measures the ability to detect sustained pressure. Two balls of different weights (a ping pong ball and a golf ball) are placed on the palm of the hand or held by the participant in a carefully standardised manner. The participant reports the intensity of the sensation on a 
scale of zero to ten immediately after the ball is placed on the hand and then at 5 , 10, 15 and 20 seconds. Good reliability was found for all tests except the passive STP for the light ball which was removed. Both tests were related to measures of touch perception and stereognosis used for people with peripheral nerve lesions and hand injuries; Semmes-Weinstein filaments (45) and the Moberg Recognition test (46). Weak to moderate relationships were found with established measures of dexterity and upper limb impairment in the Box and Block test (47) and TEMPA(48). Responsiveness has not been addressed, nor has the construct of the test and it has not been established whether there is any redundancy in the testing protocol.

Eek \& Engardt (49) used high frequency transcutaneous nervous stimulation to evaluate the threshold at which touch was perceived (Touch Perception Threshold test). A programmable transcutaneous nervous stimulation machine, delivered a high-frequency constant current of $40 \mathrm{~Hz}$; a level of sensation which produced a tingling sensation in healthy volunteers. The electrodes were applied to the tip of the index finger and the palm of each hand, and the 'bulb' of the big toe and the front arch of each foot. The intensity of stimulation was increased until the patient indicated that they could feel it. The scoring for patients who could not feel the stimulation at all is not reported. Excellent inter-tester and test-retest reliability was found for both the hand and feet. The limits of agreement showed that the device could detect changes above $1 \mathrm{~mA}$ for the hand and $5 \mathrm{~mA}$ for the feet. The higher error for the foot was mainly from lower inter-tester reliability (Table 2 and 3). Validity, particularly the assumption that the ability to perceive the tingling sensation produced by transcutaneous nervous stimulation is analogous to the ability to perceive cutaneous tactile sensation remains untested. The authors noted outlier 
values, which appeared to be participants with limited peripheral circulation, who could have had sub-acute peripheral nerve lesions that limited their ability to feel the stimulation.

\section{DISCUSSION}

The results of this review have identified several user-friendly assessments of sensory impairment. Although none fulfilled all of the psychometric criteria, the Erasmus version of the Nottingham Sensory assessment and the Sensory section of the Fugl-Meyer Assessment showed the best balance of clinical utility and psychometric properties. The recommendation for further psychometric testing on the Fugl-Meyer Assessment has previously been recognised(43).

For the ordinal scales, limited reliability was a short-coming particularly between testers, however this was improved with careful standardisation and detailed operating instructions. This highlights the importance of the manner of administration, particularly in the clinical setting when multiple people are likely to test the patient over the course of their rehabilitation.

Another issue with the ordinal scales was redundancy of items. This not only means that testing takes longer than necessary, it is also likely to artificially inflate or deflate scores as patients will essentially answer the same questions more than once. Further work is needed with either scale to remove item redundancy and establish a hierarchy (if one exists) to improve the testing time and meaningfulness of the data obtained. 
An increasingly popular way of doing this is with Rasch analysis (50). However the translation of measurement tools into clinically useable measures following Rasch analysis is scarce (51). All ordinal scales are nonlinear and the raw score remains so even when data fit the Rasch model (50) unless the data are transformed into 'Rasch' scores with interval properties. Future work needs to establish clinically feasible ways to achieve this, such as the item map and (freely available) computer programme recently produced for the Gross Motor Function Measure-66 (52).

Several simple instrumented measures $((26,27))$ produced robust data on tactile sensation and appear reasonably feasible to use but only assessed one modality. All are time consuming, appear to have redundancy in their testing protocols and are only available to the reporting authors. They are therefore of limited utility. The authors are urged to make the equipment available either commercially or by publishing the instructions so that they can be made in a standardised fashion by other workers.

Like most measures in neurological rehabilitation, none of the tools drew on a clear theoretical construct to guide the choice of sensory modalities to be tested or the manner of testing. Most are based, to a greater or lesser extent, on a traditional clinical assessment. The purpose of such an assessment is primarily to diagnose the pathological cause of the patients' problems. It therefore focuses on the presence or absence of clinical features that relate to pathologies. However in rehabilitation, measures of sensory impairment serve a different purpose; they are to diagnose the presence or absence of sensory impairment(s) and/or describe their severity with a 
view to planning, or evaluating the effects of, treatment. To fulfil both functions effectively would requires two different tests. Firstly, a screening assessment to identify the presence of disabling sensory impairments and secondly, a measure of the severity of the impairments, which is responsive to change. For both, to be effective we need to know which modalities should be tested and how. The validity studies examined in the present paper have shown that the relationship between sensory impairments and function are not strong. As maximising function and wellbeing is the ultimate goal of rehabilitation, then the mere presence of impairment is insufficient to require treatment or measurement; we need to know that it impacts on function. Significant relationships between tactile sensation (light touch or pressure) and proprioception in the hands and feet have been found with measures of activity and are therefore logical inclusions, especially as reliable ways of assessing these have been established. The functional significance of other modalities such as temperature recognition, discriminatory tactile skills (such as texture), vibration, two point discrimination or bilateral extinction need to be justified before they are added.

A prototype screening tool has been identified by Tyson and co-workers (41) based on the Rivermead Assessment of Somato-sensory Perception measures of proprioception and tactile sensation which classifies them as 'intact', 'impaired' or 'absent' by merely testing one area and one joint of the affected hand and foot. To evaluate the effectiveness of this simple, quick test as a screening tool, further work is needed to assess the sensitivity and specificity against a full clinical assessment. Such work, and that of other potential screening tools, needs to use diagnostic testing methods (such as sensitivity/ specificity or the area under the RoC curve), 
rather than merely looking for differences between groups, which has been prevalent in previous studies.

Tests of the severity of sensory impairments need to justify the included impairments in terms of their impact on function or well-being. They should also attend carefully to the structure and construct of the tool to ensure that testing protocols are as quick and effective as possible, and produce robust, meaningful data. The optimal type of data is moot. Ordinal data lends itself to simple and meaningful categorisation of patients' problems, which aids communication and decisions about the effectiveness of interventions, but are notoriously unresponsive to change. Whereas continuous data is inherently more sensitive, which is advantageous when assessing impairment severity. However a clear understanding of the clinical/functional significance of any changes is needed when interpreting the data.

The main limitation of this review lies in the thoroughness of the searching strategies. The lack of consensus on the terms used to describe sensory impairments and the wide variety of impairments that are measured made it a challenge to develop effective search strategies and we may have missed some measurement tools. A recent Cochrane Review of the effectiveness of interventions for sensory impairment in the upper limb after stroke selected 13 studies which used 36 different measures of sensory impairment, many of which were not identified in this review. However on investigation, those tests had no publications or descriptions of their psychometric properties, which explained why they were not identified in this review. The authors of the Cochrane review concluded that there was insufficient evidence to support or refute the effectiveness of interventions for sensory 
impairments and called for more well-designed, better reported studies of sensory rehabilitation. To this should be added a plea that such studies need to include measurement tools which demonstrably produce robust data which is relevant and important to function. Furthermore we only searched for measurement tools in English and adults so there may be measures in other languages or children which we have missed.

Clinical Messages

- Currently, the sensory section of the Fugl-Meyer Assessment and the Erasmus MC version of the Nottingham Sensory Assessment show the best balance of usability and robustness

- Varied reports of reliability highlighted the importance of the manner of administration. Clinicians need to ensure careful standardisation of the measurement tools and that detailed operating instructions are followed.

\section{References}

1. Jørstad EC, Hauer K, Becker C, Lamb SE. Measuring the Psychological Outcomes of Falling: A Systematic Review. Journal of the American Geriatrics Society. 2005;53:501-10.

2. American Occupational Therapy Association. Standards of Practice for Occupational Therapy American Journal of Occupational Therapy. 2010;64.

3. Chartered Society of Physiotherapy. Core Standards of Physiotherapy Practice. London, UK 2005.

4. College of Occupational Therapists. Professional standards for occupational therapy practice. London: COT; 2007.

5. Wade DT. Barriers to rehabilitation research, and overcoming them. Clinical Rehabilitation. 2003;17:1-4.

6. Kwakkel G, Wagenaar R, Koelman T, Lankhorst G, Koestier J. Effects of intensity of rehabilitation after stroke: A research synthesis. Stroke. 1997;28:1550-6. 
7. Doyle S, Bennett S, Fasoli S, McKenna K. Interventions for sensory impairment in the upper limb after stroke. Cochrane Database of Systematic Review. 2010:Art. No.: CD006331.

8. Intercollegiate Stroke Working Party. National Clinical Guideline for Stroke (3rd Edition) London UK; 2008.

9. The National Collaborating Centre for Chronic Conditions. Multiple Sclerosis: National clinical guideline for diagnosis and management in primary and secondary care. London: Royal College of Physicians; 2004.

10. Royal College of Physicians and British Society of Rehabilitation Medicine. Rehabilitation following acquired brain injury: national clinical guidelines London: RCP, BSRM 2003.

11. Doyle S, Bennett S, Fasoli SE, McKenna KT. Interventions for sensory impairment in the upper limb after stroke. Cochrane Database of Systematic Reviews. 2010.

12. Tyson S, Hanley M, Chillala J, Selley AB, Tallis RC. Sensory Loss in HospitalAdmitted People With Stroke: Characteristics, Associated Factors and Relationship With Function. Neurorehabil Neural Repair. 2008 August 8, 2007;22:166-72.

13. Connell L, Lincoln N, Radford K. Somatosensory impairment after stroke: frequency of different deficits and their recovery. Clinical Rehabilitation. 2008;22:758-67.

14. Shaffer SW, Harrison AL. Aging of the somatosensory system: a translational perspective. PHYS THER. 2007 Feb;87:193-207.

15. Winward CE, Halligan PW, Wade DT. Current practice and clinical relevance of somatosensory assessment after stroke. Clinical Rehabilitation. 1999;13:48-55.

16. Tyson S, Connell L, On behalf of the GMOM Project steering group. The psychometric properties and clinical utility of measures of walking and mobility in neurological conditions: A systematic review Clinical Rehabilitation. 2009;23:101833.

17. Tyson S, Connell L, on behalf of the GMOM project steering group. How to measure balance activity in clinical practice? A systematic review of the psychometric properties and clinical utility of measurement tools for neurological conditions. Clinical Rehabilitation. 2009;23:824-40.

18. Niessen $M$, Veeger D, Koppe $P$, Konijnenbelt $M$, van Dieën J, Janssen $T$. Proprioception of the shoulder after stroke. . Archives of Physical Medicine and Rehabilitation. 2008;89:333-8.

19. Lin S-I. Motor function and joint position sense in relation to gait performance in chronic stroke patients. Archives of Physical Medicine and Rehabilitation. 2005;86:197-203.

20. Dukelow S, Herter T, Moore K, Demers M, Glasgow J, Bagg S, et al. Quantitative assessment of limb position sense following stroke. Neurorehabil Neural Repair. 2010;24:178-87.

21. Wingert J, Burton H, Sinclair R, Brunstrom J, Damiano D. Joint-position sense and kinesthesia in cerebral palsy. Archives of Physical Medicine and Rehabilitation. 2009;90:447-53.

22. Leibowitz N, Levy N, Weingarten S, Grinberg Y, Karniel A, Sacher $Y$, et al. Automated measurement of proprioception following stroke. Disability \& Rehabilitation. 2008;30:1829 - 36.

23. Kamon N. Quantitative measurement of vibratory perception threshold using a new vibrometer TM-31A. . J of Occup Med. 1994;36:989-96. 
24. Halonen $\mathrm{P}$, Panelius $\mathrm{M}$, Halonen $\mathrm{J}$, Lang $\mathrm{H}$. Vibratory perception threshold in patients with mild multiple sclerosis. Acta Neurol Scand. 1986;74:63-5.

25. Heijenbrok M, Anema J, Faes T, Bertelsmann F, Heimans J, Polman C. Quantitative measurement of vibratory sense and temperature sense in patients with multiple sclerosis. Electromyogr Clin Neurophysiol. 1992;32:385-8.

26. Brown L, Metz L, Sainsbury R. Sensory temporal thresholds and interhemispheric transfer times in multiple sclerosis: a preliminary study of a new outcome measure. J Clin Exp Neuropsychol. 2003;25:783-92.

27. Brown L, Metz L, Eliasziw M. Identifying reliable change in tactile temporal thresholds in multiple sclerosis: test-retest reliability Multiple Sclerosis. 2006;12:5737.

28. Carey LM, Oke LE, Matyas TA. Impaired limb position sense after stroke: A quantitative test for clinical use. Archives of Physical Medicine and Rehabilitation. 1996;77:1271-8.

29. Carey LM, Oke LE, Matyas T. Impaired Touch Discrimination After Stroke: A Quantitative Test. J Neuro Rehab. 1997;11:219-32.

30. Williams P, Basso M, Case-Smith J, Nichols-Larsen D. Development of the Hand Active Sensation Test: reliability and validity. Archives of Physical Medicine and Rehabilitation. 2006;87:1471-7.

31. Miller K, Phillips B, Martin C, Wheat H, Goodwin A, Galea M. The AsTex ${ }^{\circledR}$ : clinimetric properties of a new tool for evaluating hand sensation following stroke Clinical Rehabilitation. 2009;23:1104-15.

32. Lincoln NB, Crow JL, Jackson JM, Waters GR, Adams SA, Hodgson P. The unreliability of sensory assessment. Clinical Rehabilitation. 1991;5:273-82.

33. Lincoln NB, Jackson JM, Adams SA. Reliability and Revision of the Nottingham Sensory Assessment for Stroke Patients. Physiotherapy. 1998 August;84:358-65.

34. Stolk-Hornsveld F, Crow JL, Hendriks EP, van der Baan R, Harmeling-van der Wel BC. The Erasmus MC modifications to the (revised) Nottingham Sensory Assessment: a reliable somatosensory assessment measure for patients with intracranial disorders. Clin Rehabil. 2006 Feb;20:160-72.

35. American Society for Surgery of the Hand. American Society for Surgery of the Hand: The Hand: Examination and Diagnosis. Aurora, CO.; 1978.

36. Connell LA. Sensory Impairment and Recovery after Stroke. Nottingham: University of Nottingham; 2007 [cited. Available from: http://etheses.nottingham.ac.uk/247/.

37. Tesio L. Measuring Behaviours and Perceptions: Rasch Analysis as a Tool for Rehabilitation Research. J Rehabil Med. 2003;35:105-15.

38. Gaubert CS, Mockett SP. Inter-rater reliability of the Nottingham method of stereognosis assessment. Clinical Rehabilitation. 2000;14:153-9.

39. Winward C, Halligan P, Wade D. Somatosensory Assessment after central nerve damage: the need for standardised assessments. Physical Therapy Reviews. 1999;4:21-8.

40. Winward CE, Halligan PW, Wade DT. The Rivermead Assessment of Somatosensory Performance (RASP): standardisation and reliability data. Clinical Rehabilitation. 2002;16:523-33.

41. Tyson S, Busse M. How many body locations need to be tested when assessing sensation after stroke? An investigation of redundancy in the Rivermead Assessment of Somato-sensory Perception. Clinical Rehabilitation. 2009;23:91-5. 
42. Fugl-Meyer A, Jaasko L, Leyman I, Olsson S, Steglind S. The post-stroke hemiplegic patient: a method for evaluation of physical performance. Scand J Rehab Med. 1975;7:13-31.

43. Lin J, Hsueh I, Sheu C, Hsieh C. Psychometric properties of the sensory scale of the Fugyl-Meyer Assessment in stroke patients. Clinical Rehabilitation. 2004;18:391-7.

44. Dannenbaum RM, Michaelsen SM, Desrosiers J, Levin MF. Development and validation of two new sensory tests of the hand for patients with stroke. Clinical Rehabilitation. 2002 Sep;16:630-9.

45. Semmes J, Weinstein S, Ghent L, Teuber HL. Somatosensory Changes after Penetrating Brain Wounds in Man. Cambridge: Harvard University Press; 1960.

46. Moberg E. Objective methods for determining the functional value of sensibility in the hand. J Bone Joint Surg. 1958;40B:454.

47. Mathiowetz V, Volland G, Kashman N, Weber K. Adult norms for the Box and Block Test of manual dexterity American Journal of Occupational Therapy. 1985;39:386-91.

48. Desrosiers J, Herbert R, Dutil E, Bravo G, Mercier L. Validity of the TEMPA: a measurement instrument for upper extremity performance. Occup Ther $\mathrm{J}$ Res. 1994;14:267-81.

49. Eek E, Engardt M. Assessment of the perceptual threshold of touch (PTT) with high-frequency transcutaneous electric nerve stimulation ( $\mathrm{Hf} / T E N S)$ in elderly patients with stroke: a reliability study. Clinical Rehabilitation. 2003 Dec;17:825-34.

50. Tesio L, Simone A, Bernardinello M. Rehabilitation and outcome measurement: where is Rasch analysis going? Eura Medicophys. 2007;43:417-26.

51. Tennant A, McKenna SP, Hagell P. Application of Rasch Analysis in the Development and Application of Quality of Life Instruments. Value in Health. 2004;7:S22-S6.

52. Burrows L. Gross Motor Ability Estimator [software]. Hamilton, Ontario, Canada: CanChild Centre for Childhood Disability Research, McMaster University; 1999. p. (Software available from the CanChild website at: http://www.fhs.mcmaster.ca/canchild). 
Table 1: The clinical utility of the selected measurement tools

\begin{tabular}{|c|c|c|c|c|c|}
\hline Measurement Tool & Time to complete & Cost & Portability & $\begin{array}{l}\text { Specialist } \\
\text { equipment }\end{array}$ & $\begin{array}{l}\text { Total } \\
(\max =10)\end{array}$ \\
\hline $\begin{array}{l}\text { Nottingham Sensory Assessment (including } \\
\text { revised version) }\end{array}$ & $\begin{array}{l}45-60 \text { minutes for the } \\
\text { whole assessment }=1\end{array}$ & 3 & 2 & 1 & 7 \\
\hline Erasmus modifications of NSA (Em-NSA) & $10-15$ minutes $=3$ & 3 & 2 & 1 & 9 \\
\hline Stereognosis section of the NSA & 3 & 3 & 2 & 1 & 9 \\
\hline $\begin{array}{l}\text { Rivermead Assessment of Somatosensory } \\
\text { Perception }\end{array}$ & $20-30$ minutes $=2$ & 2 & 2 & 1 & 7 \\
\hline Sensory section of Fugl-Meyer Assessment & $\begin{array}{l}\text { Not stated but estimated } \\
\text { at } 15 \text { minutes }=3\end{array}$ & 3 & 2 & 1 & 9 \\
\hline Moving \& Sustained Touch-Pressure tests & $\begin{array}{l}\text { Up to } 30 \text { minutes for } \\
\text { both }=2\end{array}$ & 3 & 2 & 1 & 8 \\
\hline Touch Perception Threshold & $10-20$ minutes $=2$ & 1 & 2 & 0 & 5 \\
\hline
\end{tabular}

Scoring

- Time taken to administer, analyse and interpret the measurement tool: $3=<10$ minutes $2=10-30$ minutes $1=30-60$ minutes $0=>1$ hours

- Cost

$3=<£ 100 \quad 2=£ 100-£ 500 \quad 1=£ 500-£ 1,000 \quad 0=>£ 1000$ or Unknown

- Does the measurement tool need specialist equipment and training to use? 
$2=$ No: $\quad 1=$ Yes, but simple \& clinically feasible: 0 = yes and not feasible for use clinical use $/$ Unknown

- Is the measurement tool portable? Can it be taken to the patient?

2 = yes easily (can fit in a pocket): $1=$ Yes (in a briefcase or trolley) $0=$ No or very difficult 
Table 2: Details of the psychometrics of the selected measurement tools

\begin{tabular}{|c|c|c|c|c|c|}
\hline Reference & $\begin{array}{l}\text { Psychometric } \\
\text { Property tested }\end{array}$ & Subjects & Procedure & Analysis & Results \\
\hline Lincoln et al (32) & $\begin{array}{l}\text { Inter-tester \& } \\
\text { test-retest } \\
\text { reliability of } \\
\text { Nottingham } \\
\text { Sensory } \\
\text { Assessment }\end{array}$ & $\begin{array}{l}\text { Test-retest } \\
20 \text { community } \\
\text { living chronic } \\
\text { strokes, } \\
\text { Age = 55-83 } \\
\text { years } \\
\text { Inter-tester } \\
20 \text { acute strokes } \\
\text { Age } 47-81 \text { yrs }\end{array}$ & $\begin{array}{l}\text { Test-retest } \\
1 \text { physio tested } \\
\text { on } 2 \text { occasions } \\
\text { (2/52 apart) } \\
\text { Inter-tester: } \\
\text { Assessed by } 2 \\
\text { physios within } \\
\text { 2/52 of each } \\
\text { other }\end{array}$ & $\begin{array}{l}\text { Kappa } \\
\text { coefficients }\end{array}$ & $\begin{array}{l}\underline{\text { Test-retest }} \\
\mathrm{K}=-0.13-0.92 \\
\mathrm{k}>0.7 \text { for } 17 / 54 \text { items } \\
\underline{\text { Inter-tester: }} \\
\mathrm{K}=0.01-0.89 \\
\text { only } 1 \text { item } \mathrm{k}>0.7\end{array}$ \\
\hline Connell (36) & $\begin{array}{l}\text { Validity of the } \\
\text { original } \\
\text { Nottingham } \\
\text { Sensory } \\
\text { Assessment }\end{array}$ & $\begin{array}{l}70 \text { strokes } \\
\text { within } 5 \text { days of } \\
\text { admission to } \\
\text { rehab unit } \\
\text { Mean age = } \\
71 y r s \text { (sd = 10) } \\
\text { Median time }\end{array}$ & $\begin{array}{l}\text { All testing } \\
\text { completed on } \\
\text { one day }\end{array}$ & $\begin{array}{l}\text { Pearson } \\
\text { correlations }\end{array}$ & $\begin{array}{l}\text { Validity wrt } \\
\text { NIHSS } r=0.5-0.6 \\
\text { P<0.01 } \\
\text { RMA } r=0.29-0.59, \\
p<0.02) \\
\text { BI } r=0.35-0.51, p<0.05)\end{array}$ \\
\hline
\end{tabular}




\begin{tabular}{|c|c|c|c|c|c|}
\hline & & $\begin{array}{l}\text { since stroke }= \\
15 \text { days (IRQ= } \\
8-19 \text { days) }\end{array}$ & & & \\
\hline Lincoln et al (33) & $\begin{array}{l}\text { Inter-tester } \\
\text { reliability of the } \\
\text { Revised } \\
\text { Nottingham } \\
\text { Sensory } \\
\text { Assessment }\end{array}$ & $\begin{array}{l}27 \text { acute strokes } \\
\text { (13 male, } \\
\text { 10=Right sided } \\
\text { stroke). }\end{array}$ & $\begin{array}{l}\text { Tests repeated } \\
\text { by } 2 \text { physios } \\
\text { within 3-4 days } \\
\text { of each other. }\end{array}$ & $\begin{array}{l}\text { Kappa } \\
\text { coefficients }\end{array}$ & $\mathrm{K}>0.7$ in $12 / 86$ items \\
\hline $\begin{array}{l}\text { Gaubert \& } \\
\text { Mockett } \\
(38)\end{array}$ & $\begin{array}{l}\text { Inter-tester } \\
\text { reliability of the } \\
\text { stereognosis } \\
\text { section of the } \\
\text { Nottingham } \\
\text { Sensory } \\
\text { Assessment }\end{array}$ & $\begin{array}{l}20 \text { acute strokes } \\
\text { in stroke unit } \\
\text { (11 male), Mean } \\
\text { age }=70 y r s . \\
\text { Mean time since } \\
\text { stroke }=4 \\
\text { weeks }\end{array}$ & $\begin{array}{l}\text { Stereognosis } \\
\text { section tested } \\
\text { within } 24 \text { hrs by } \\
2 \text { out of } 3 \\
\text { testers }\end{array}$ & $\begin{array}{l}\text { Kappa } \\
\text { coefficient }\end{array}$ & $\begin{array}{l}K=0.4-0.85 \\
k>0.7 \text { in } 5 / 10 \text { items }\end{array}$ \\
\hline $\begin{array}{l}\text { Stolk-Hornsveld } \\
\text { et al (34) }\end{array}$ & $\begin{array}{l}\text { Inter-tester and } \\
\text { test-retest } \\
\text { reliability of the } \\
\text { Em-NSA }\end{array}$ & $\begin{array}{l}18 \text { (9 male) with } \\
\text { stroke }(n=12) \text { or } \\
\text { neurosurgical } \\
(n=4) \text { disorders } \\
\text { Mean age }=58\end{array}$ & $\begin{array}{l}\text { Test-retest } \\
2 \text { physios } \\
\text { assessed the } \\
\text { patients twice, } \\
\text { at least } 24\end{array}$ & $\begin{array}{l}\text { Kappa co- } \\
\text { efficient }\end{array}$ & $\begin{array}{l}\text { Test-retest } \\
\text { For } 81 \% \text { of items } \\
k>0.75) \\
\frac{\text { Inter-tester }}{77 \% \text { of items showed }}\end{array}$ \\
\hline
\end{tabular}




\begin{tabular}{|c|c|c|c|c|c|}
\hline & & $\begin{array}{l}\text { years (range } \\
20-84 \text { ) } \\
\text { Mean days } \\
\text { since admission } \\
=15 \text { (range 4- } \\
92 \text { ). }\end{array}$ & $\begin{array}{l}\text { hours apart. } \\
\text { Inter-tester } \\
2 \text { physios } \\
\text { tested each } \\
\text { patient on the } \\
\text { same day 1-2 } \\
\text { hours apart }\end{array}$ & & $\mathrm{k}>0.75$ \\
\hline $\begin{array}{l}\text { Winward et al. } \\
\text { (40) }\end{array}$ & $\begin{array}{l}\text { Rivermead } \\
\text { Assessment of } \\
\text { Somato-sensory } \\
\text { Perception } \\
\text { (RASP): } \\
\text { Inter-Reliability, } \\
\text { intra-reliability } \\
\text { and validity }\end{array}$ & $\begin{array}{l}100 \text { acute } \\
\text { strokes (50 left } \\
\text { hemi). } \\
\text { Age 23-96 } \\
\text { Controls: Non } \\
\text { brain injured } \\
\text { individuals } \\
\text { (age=24-80 } \\
\text { years) }\end{array}$ & $\begin{array}{l}\text { Test-retest: } 1 \\
\text { physio } \\
\text { repeated test } \\
\text { on } 12 \text { pts within } \\
\text { 30days of } 1^{\text {st }} \\
\text { assessment } \\
\text { Validity: } \\
\text { compared with } \\
\text { RMA, MI \& BI }\end{array}$ & $\begin{array}{l}\text { Test-retest } \\
\text { Bland Altman } \\
\text { plot for } \\
\text { differences in } \\
\text { total scores } \\
\text { Validity: } \\
\text { Spearman } \\
\text { correlations }\end{array}$ & $\begin{array}{l}\text { Test-retest- variability of } \\
30-40 / 360 \text { points (8- } \\
11 \%) \text { and no systematic } \\
\text { bias. } \\
\text { Validity: weak Wrt } \\
\text { MI }(r=0.08-0.36,) \\
\text { BI = (r=0.09-0.41), } \\
\text { RMA }=0.05-0.32\end{array}$ \\
\hline Tyson et al (12) & $\begin{array}{l}\text { Validity of the } \\
\text { RASP wrt } \\
\text { Independence in } \\
\text { ADL (BI), and }\end{array}$ & $\begin{array}{l}102 \text { acute } \\
\text { strokes with } 4 \\
\text { weeks of stroke. } \\
\text { (54 male). }\end{array}$ & $\begin{array}{l}\text { All tested } \\
\text { completed on } \\
\text { one day by one } \\
\text { of four tester, }\end{array}$ & $\begin{array}{l}\text { Validity: } \\
\text { Spearman } \\
\text { correlations }\end{array}$ & $\begin{array}{l}\text { Validity wrt } \\
\mathrm{BI}=0.541(p<.000) \\
\mathrm{RMI}=0.515(p<.000)\end{array}$ \\
\hline
\end{tabular}




\begin{tabular}{|c|c|c|c|c|c|}
\hline & mobility (RMI) & $\begin{array}{l}\text { Mean age }=71 \\
\text { (SD13) years. }\end{array}$ & & & \\
\hline Lin et al. (43) & $\begin{array}{l}\text { Inter-tester } \\
\text { reliability, and } \\
\text { validity of the } \\
\text { Sensory Scale of } \\
\text { the Fugl-Meyer } \\
\text { Assessment }\end{array}$ & $\begin{array}{l}176 \text { acute } \\
\text { strokes tested at } \\
14,30,90,180 \\
\text { days post-stroke }\end{array}$ & $\begin{array}{l}\text { Inter-rater: } \\
2 \text { OTs tested } \\
\text { @ } 30 \text { days } \\
\text { post-stroke } \\
\text { within 48hrs of } \\
\text { each other } \\
\text { Validity } \\
\text { compared with } \\
\text { Barthel Index \& } \\
\text { Motor scale of } \\
\text { FMA. }\end{array}$ & $\begin{array}{l}\text { Inter-rater = } \\
\text { weighted } \\
\text { Kappa } \\
\text { Internal } \\
\text { consistency = } \\
\text { Cronbach's } \\
\text { Alpha } \\
\text { Validity = } \\
\text { Spearman's } \\
\text { correlation }\end{array}$ & $\begin{array}{l}\text { Inter-rater } \mathrm{K}=0.3-0.9 \\
\text { Light touch = weak- } \\
\text { moderate }(\mathrm{K}=0.3-0.55) \text {, } \\
\text { proprioception }= \\
\text { excellent }(0.71-0.99) \\
\text { Validity wrt } \\
\text { BI r = 0.38-0.53, } \\
\text { p<0.001 } \\
\text { FMA-M r = 0.31-0.44 } \\
p<0.001\end{array}$ \\
\hline $\begin{array}{l}\text { Dannenbaum et } \\
\text { al(44) }\end{array}$ & $\begin{array}{l}\text { Moving Touch } \\
\text { Pressure (MTP) } \\
\text { \& Sustained } \\
\text { Touch-Pressure } \\
\text { (SPT) tests: } \\
\text { Test-retest } \\
\text { reliability Inter- }\end{array}$ & $\begin{array}{l}28 \text { chronic } \\
\text { strokes stroke } \\
\text { patients: } \\
(17 \text { male), } \\
\text { Mean age = } 69 \\
\text { (13) years } \\
\text { Mean time }\end{array}$ & $\begin{array}{l}\text { Test-retest: } \\
\text { tests repeated } \\
2 x, 1-3 / 52 \\
\text { apart } \\
\text { Inter-tester: } \\
\text { testing by } 2 \\
\text { physios on }\end{array}$ & $\begin{array}{l}\text { Reliability: } \\
\text { ICC } \\
\text { Validity: } \\
\text { Spearman } \\
\text { correlations }\end{array}$ & $\begin{array}{l}\text { Test-retest: MTP ICC } \\
=0.92, \\
\text { STP ICC }=0.62-0.92 \\
\text { Inter-rater: MTP } \\
\text { ICC=0.92, } \\
\text { STP ICC =0.66-0.94 } \\
\text { Validity: Both tests }\end{array}$ \\
\hline
\end{tabular}




\begin{tabular}{|c|c|c|c|c|c|}
\hline & $\begin{array}{l}\text { rater reliability } \\
\text { Concurrent } \\
\text { validity }\end{array}$ & $\begin{array}{l}\text { since stroke }=24 \\
\text { (3) months }\end{array}$ & $\begin{array}{l}\text { same day } \\
\text { Validity: } \\
\text { Compared with } \\
\text { Semmes- } \\
\text { Weinstein } \\
\text { filaments, } \\
\text { Moberg } \\
\text { recognition } \\
\text { test, box \& } \\
\text { Block test and } \\
\text { TEMPA }\end{array}$ & & $\begin{array}{l}\text { correlated with filament } \\
\text { test }(r=0.49, p<0.01)\end{array}$ \\
\hline $\begin{array}{l}\text { Eek \& Engardt } \\
\text { (49) }\end{array}$ & $\begin{array}{l}\text { Touch Perception } \\
\text { Threshold: } \\
\text { Inter-tester } \\
\text { test-retest } \\
\text { reliability, } \\
\text { measurement } \\
\text { error }\end{array}$ & $\begin{array}{l}32 \text { elderly stroke } \\
\text { patients. } \\
\text { Mean age } \\
=79 y r s, \\
13 \text { male }\end{array}$ & $\begin{array}{l}\text { Test-retest: } \\
\text { subjects tested } \\
1 \text { day apart } \\
\text { Inter-tester: } 2 \\
\text { testers on the } \\
\text { same day }\end{array}$ & $\begin{array}{l}\text { Reliability: } \\
\text { ICC } \\
\text { measurement } \\
\text { error: Limits of } \\
\text { agreement }\end{array}$ & $\begin{array}{l}\text { Inter-rater ICC=0.94- } \\
0.98 \\
\text { Test-retest: ICC }=0.98- \\
0.99 \\
\text { Limits of agreement = } \\
1 \mathrm{~mA} \text { for the hand } \\
5 \mathrm{~mA} \text { for the foot }\end{array}$ \\
\hline
\end{tabular}


Abbreviations: NIHSS = National Institute for Health Stroke Scale, BI = Barthel Index, RMA= Rivermead Motor Assessment. RMI = Rivermead Motor Assessment, ICC = Interclass Correlation Co-efficient, FMA = Fugl-Meyer Assessment, wrt = with respect to, RASP = Rivermead Assessment of Somato-sensory Perception, MI = Motricity Index, SD= Standard deviation. 
Table 3: Summary of the psychometric properties of the selected measurement tools

\begin{tabular}{|c|c|c|c|c|c|}
\hline & $\begin{array}{l}\text { Groups for whom } \\
\text { it is validated }\end{array}$ & Validity & $\begin{array}{l}\text { Test- } \\
\text { retest } \\
\text { reliability }\end{array}$ & $\begin{array}{l}\text { Inter- } \\
\text { tester } \\
\text { reliability }\end{array}$ & $\begin{array}{l}\text { Ability to detect } \\
\text { change }\end{array}$ \\
\hline $\begin{array}{l}\text { Nottingham Sensory Assessment } \\
\text { (original) }\end{array}$ & Stroke & $+/++$ & ++ & + & Not tested \\
\hline $\begin{array}{l}\text { Nottingham Sensory Assessment } \\
\text { (Revised) }\end{array}$ & Stroke & $\begin{array}{l}\text { Not } \\
\text { tested }\end{array}$ & ++ & ++ & Not tested \\
\hline $\begin{array}{l}\text { Em- Nottingham Sensory } \\
\text { Assessment }\end{array}$ & $\begin{array}{l}\text { Stroke, neurological } \\
\text { and neurosurgical } \\
\text { disorders }\end{array}$ & $\begin{array}{l}\text { Not } \\
\text { tested }\end{array}$ & $++/+++$ & $++/+++$ & Not tested \\
\hline Stereognosis section of NSA & Stroke & $\begin{array}{l}\text { Not } \\
\text { tested }\end{array}$ & & $++/+++$ & Not tested \\
\hline $\begin{array}{l}\text { Rivermead Assessment of } \\
\text { Somato-sensory Perception }\end{array}$ & $\begin{array}{l}\text { Acute stroke and } \\
\text { neurological } \\
\text { conditions }\end{array}$ & ++ & ++ & ++ & Not tested \\
\hline $\begin{array}{l}\text { Sensory Section of Fugl-Meyer } \\
\text { Assessment }\end{array}$ & Stroke & + & Not tested & +++ & $+/++$ \\
\hline $\begin{array}{l}\text { Moving \& Sustained Touch- } \\
\text { Pressure tests: }\end{array}$ & Stroke & $++/+++$ & $\begin{array}{l}\text { MTP +++ } \\
\text { STP }\end{array}$ & $\begin{array}{l}\text { MTP +++ } \\
\text { STP }\end{array}$ & Not tested \\
\hline
\end{tabular}




\begin{tabular}{|l|l|l|l|l|l|}
\hline & & & $++/+++$ & $++/+++$ & \\
\hline Touch Perception Threshold & Stroke & $\begin{array}{l}\text { Not } \\
\text { tested }\end{array}$ & +++ & +++ & $\begin{array}{l}1 \mathrm{~mA} \text { for the hand } \\
5 \mathrm{~mA} \text { for the foot }\end{array}$ \\
\hline
\end{tabular}

Key to the strength of the psychometric properties(1):

$+\quad$ weak reliability or validity $=$ scores of $0.4-0.6$;

$+\quad$ moderate reliability or validity $=$ scores of 0.6-0.8

+++ good reliability or validity $=$ scores of 0.8 and above 